\title{
PRO DAN KONTRA TERHADAP KEBIJAKAN MANTAN NARAPIDANA KORUPSI DALAM PENCALONAN LEGISLATIF
}

\author{
Alvin Fauzi ${ }^{1}$, Haryadi $^{2}$ \\ ${ }^{1}$ Departemen Politik, Fakultas Ilmu Sosial dan Ilmu Politik, Universitas Airlangga \\ alvinfauzii@yahoo.co.id \\ ${ }^{2}$ Departemen Politik, Fakultas Ilmu Sosial dan Ilmu Politik, Universitas Airlangga \\ haryadi@fisip.unair.ac.id
}

\begin{abstract}
This study discusses the prohibition of ex-corruption convicts who registered themselves as legislative candidates. Even this is supported by Article 7 paragraph 1 letter g PKPU. However, the Bawaslu (Election Oversight Body) allowed it and it is also supported by Yasonna Laoly, Minister of Justice and Human Rights of Indonesia, with the consideration that the regulations stipulated by PKPU contradict Law No. 7 of 2017 which states that ex-convicts are considered to have the same political rights as other citizens, a right guaranteed by the constitution. This study employs political contestation theory that explains the actions or processes that are disputed, for example ideological contestation on social policy, as well as political electoral theory that explains a system for making political decisions in which individuals gain the power to decide through competitive over people's voices.
\end{abstract}

Keywords: Ex-Corruptor, Legislative Candidates and Political Party

\section{PENDAHULUAN}

Indonesia sebagai negara hukum memiliki konsep bahwa sebagai negara hukum yang memiliki trias politika, lembaga legislatif, eksekutif, dan yudikatifnya tidak diperbolehkan untuk bertindak atas kekuasaan dan kewenangan yang diberikan pada lembaga terkait. Namun, harus didasarkan pada kebenaran hukum yang positif, yakni Undang-Undang yang menjadi dasar sumber hukum dari sebuah negara. Setiap negara juga tidak bisa bertindak sewenang-wenang, diperlukan adanya aturan-aturan yang mengikat terhadap negara maupun masyarakat guna mengatur tata kehidupan bagi setiap warga negara tersebut.

Selain tunduk pada aturan hukum, sebagai suatu negara demokrasi mayoritas rakyat mempunyai hak suara untuk menentukan atau memberikan pengaruhnya lewat suara terhadap proses kegiatan perumusan kebijakan yang dibuat oleh pemerintah. Termasuk dalam hal pemilihan umum, dikatakan sebagai waktu yang tepat sebagai evaluasi kinerja parlemen, dimana dapat menjadi referensi untuk menggunakan hak pilih, yaitu bagi calon legislatif yang mempunyai rekam jejak yang buruk seharusnya dapat dicegah untuk terpilih kembali. Begitu sebaliknya, pemilihan umum juga bisa menjadi referensi untuk tidak memilih calon legislatif yang melakukan tindakan korupsi, kolusi, dan nepotisme. Pandangan ini dilatar belakangi karena dalam media massa, sering menyimak betapa banyaknya anggota dewan yang terlibat kasus korupsi. Hal tersebut kemudian disusul dengan meningkatnya kritik masyarakat terhadap peranan para anggota DPR yang dinilai kurang memadai. Salah satu yang menjadi sebab kelemahan tersebut, yaitu kualitas anggota DPR yang dipilih. Sudah menjadi rahasia umum bahwa money politics juga berperan besar dalam pemilihan ini dan masih banyak masyarakat yang tidak memahami bagaimana track record dari calon anggota DPR tersebut. 
Hal ini kemudian berimbas pada fungsi-fungsinya selaku penyalur aspirasi masyarakat kurang bisa dijalankan dengan memuaskan. Sehingga masih terlihat adanya ketimpangan antara peranan yang dijalankan oleh DPR dan pemerintah sebagaimana dikehendakai oleh sistem politik Indonesia (Miriam Budiardjo dan Ibrahim Ambong, 1993). Maka, kondisi ini kemudian mengakibatkan menurunnya tingkat kepercayaan publik pada legislatif.

Pada tahun 2018, muncul Peraturan KPU (PKPU) Nomor 20 Tahun 2018 tentang Pencalonan Anggota DPR RI, DPRD Provinsi dan DPRD kabupaten/kota mengenai larangan mantan narapidana korupsi yang mendaftarkan diri sebagai calon legislatif. Sebaliknya, pihak Bawaslu (Badan Pengawasan Pemilu) memperbolehkannya dan hal ini didukung oleh Menteri Hukum dan HAM, Yasonna Laoly, dengan pertimbangan bahwa peraturan PKPU tersebut berlawangan dengan UU Pemilu yang menyatakan bahwa mantan narapidana diperbolehkan mendaftarkan diri menjadi anggota legislatif namun dengan syarat ia bersifat terbuka kepada publik, menyatakan kepada masyarakat bahwa ia pernah menjadi mantan narapidana korupsi.

Penelitian ini dilakukan untuk mengetahui partai mana saja yang pro dengan Peraturan KPU (PKPU), bahwa pada intinya melarang mantan napi korupsi untuk mencalonkan anggota legislatif dan partai apa saja yang kontra dengan Peraturan KPU (PKPU) di Jawa Timur. Penelitian ini menggunakan metode kualitatif dengan subyek penelitian meliputi lima orang yang masing-masing berlatar belakang berbeda. Adapun analisis dilakukan dengan mengelompokkan data sehingga rumusan masalah dapat terjawab. Sehingga dengan adanya pro dan kontra inilah timbul permasalahan yang berjudul "Pro dan Kontra Terhadap Kebijakan Mantan Narapidana Korupsi Dalam Pencalonan Legislatif."

\section{Konstestasi dan Elektoral Politik}

Eksistensi pemilihan umum diakui oleh negara penganut asas kedaulatan rakyat dan diadakan pada semua jenis tataran politik, baik sistem demokrasi, otoriter, maupun totaliter. Oleh beberapa negara demokrasi, pemilihan umum dianggap sebagai lambang dan juga tolak ukur dari sistem demokrasi (Hanum Hapsari, 2018). Jajaran partai politik di negeri demokrasi merupakan kontestan politik yang siap menjadi bagian dari telinga Indonesia. Pada dasarnya, partai politik dilahirkan untuk memudahkan para rakyat atas haknya untuk dapat berpolitik dalam memilih dan memajukan negara atas amanat yang ada. Sebagai negara dengan sistem pemerintahan demokrasi, jumlah partai politik yang berdiri ditekankan agar tidak hanya satu, melainkan lebih dari itu. Sehingga diharapkan adanya beragam suara yang dimaksudkan untuk mewakilkan suara rakyat (Khoiril Huda dan Zulfa Azzah Fadhlika, 2018).

Adanya ragam suara ini tidak langsung memunculkan perbedaan pula pada prinsip dan sudut pandang kontestan, yang secara khusus akan menjadi salah satu faktor pemicu munculnya kontestasi di kalangan elite politik. Teori ini terdiri dari empat komponen utama, diantaranya (1) tiga jenis norma (yaitu, norma dasar, prinsip pengorganisasian, dan prosedur standar), (2) empat mode kontestasi (yaitu 
arbitrase, musyawarah, justifikasi, dan pertikaian), (3) tiga tahap implementasi norma (yaitu membentuk, merujuk, menerapkan), dan (4) tiga segmen pada siklus validasi norma (yaitu validasi formal, pengakuan sosial, validasi budaya (Antje Wiener, 2004).

Sedangkan, elektoral yaitu konstituensi permanen dan stabil otorisasi dan akuntabilitas dalam populasi yang stabil, lalu konsituensi suka rela keputusan dan beban suara bertujuan untuk mewujudkan kesetaraan individu dalam sebuah sistem politik. Istilah elektoral (electoral) sering dikaitkan dengan politik pemerintahan. Pengertian elektoral adalah pemilihan atau yang berkaitan dengan pemilih. Elektoral dalam demokrasi dapat diartikan sebagai pemilihan umum (pemilu) yang diikuti oleh seluruh lapisan masyarakat untuk memilih wakilnya di parlemen dan kepala pemerintahan. Demokrasi elektoral dapat dimaknai sebagai sebuah sistem untuk membuat keputusan-keputusan politik dimana individu-individu mendapatkan kekuasaan untuk memutuskan melalui pertarungan kompetitif memperebutkan suara rakyat (Pipit, 2004).

Elektoral merupakan bagian dari proses bagaimana negara kemudian bekerja dari proses bagaimana kekuatan politik berkompetisi dan merebut mendata pengelolaan negara melalui pemerintah yang dibentuk yang mana pemerintah menjadi bagian integral dari organisasi negara oleh organisasi politik yang mendapatkan legitimasi untuk memerintah setelah memenangkan kompetisi elektoral. Sedangkan demokrasi elektoral kerap disebut menyederhanakan luasannya dimensi demokrasi itu sendiri. Tentunya pandangan ini tidak sepenuhnya menyederhanakan dan membenahi tingkat pembenaran sekalipun relatif faktor-faktor lain yang tidak bisa diabaikan, yaitu merentang dari soal kesenjangan politik, penegakan hukum, kebebasan informasi sampai mekanisme komplain publik.

\section{Korupsi oleh Anggota Legislatif}

Keberadaan partai politik adalah salah satu wujud dari pelaksanaan hak asasi manusia tersebut untuk berkumpul, berserikat, dan mengemukakan pendapat. Selain itu juga, demi berjalannya demokrasi yang baik dalam suatu negara. Melalui institusi partai politik modern yang terstruktur adanya pemilihan umum berkala, dan beroperasinya kelompok-kelompok penekan, demokrasi berjalan sebagai suatu mekanisme atau "an institutuional arrangement for arriving at political decisions by mean of competitive struggle for the people's vote". Mayoritas anggota legislatif pun dalam melakukan pencalonan harus melalui partai politik.

Lord Acton meruntut penyebab terjadinya korupsi disebabkan karena adanya kekuasaan (power) yang bersifat absolut-sentralistis, manipulatif, kurangnya kejujuran hingga kurangnya integritas (Nye, 2009). Hal ini secara lebih luas didefinisikan menjadi, "power tends to corrupt, and absolute power corrupts absolutely; and studies shows that it particularly corrupts those who think they deserve it." Kalimat ini menyinggung bagaimana jika "kekuasaan" saja mampu memiliki kecenderungan untuk melakukan korupsi, maka kekuasaan absolut akan memunculkan kecenderungan untuk melakukan korupsi secara absolut pula. Sementara itu, studi telah menunjukkan bahwa korupsi adalah tindakan yang sangat merusak bagi siapapun pelaku yang pantas mendapatkan kerusakan itu. 
Tindak pidana korupsi tidak hanya dilakukan oleh aparat pemerintah dalam bentuk lembaga eksekutif, melainkan juga lembaga legislatif hingga yudikatif. Surat kabar atau media massa berperan penting sebagai pilar keempat demokrasi dalam memerankan pengungkapan korupsi di dalam gedung pemerintahan (Gentzkow et al., 2006).

Beberapa pelaku korupsi mengambil sejumlah besar dana dengan bekal pengetahuan bahwa hal itu merupakan kewenangan pribadi sehingga mereka mempunyai hak untuk mengambilnya. Dari berbagai kasus tindak pidana korupsi tersebut telah tergambar jelas bagaimana harta dan kekuasaan dapat mengaburkan cara berpikir aparat pemerintahan. Berikut catatan ICW mengenai penanganan perkara korupsi di sejumlah provinsi besar yang dilakukan oleh para anggota wakil rakyat pada tahun 2018.

Tabel 1. Sepuluh Provinsi Pilkada 2018 Dengan Penanganan Kasus Korupsi Terbanyak

\begin{tabular}{|l|l|c|l|l|}
\hline No & \multicolumn{1}{|c|}{ Provinsi } & $\begin{array}{c}\text { Jumlah } \\
\text { Kasus }\end{array}$ & \multicolumn{1}{|c|}{ Nilai Kerugian Negara } & \multicolumn{1}{|c|}{ Nilai Suap } \\
\hline 1 & Sumatera Utara & 237 & Rp. 1,83 trilyun & Rp. 69 trilyun \\
\hline 2 & Riau & 153 & Rp. 3,85 trilyun & Rp. 41 trilyun \\
\hline 3 & Sumatera Selatan & 89 & Rp. 348 trilyun & Rp. 2,7 trilyun \\
\hline 4 & Jawa Barat & 181 & Rp. 1,81 trilyun & Rp. 43 trilyun \\
\hline 5 & Jawa Tengah & 200 & Rp. 605,5 trilyun & Rp. 2,5 trilyun \\
\hline 6 & Jawa Timur & 281 & Rp. 1,17 trilyun & Rp. 79 trilyun \\
\hline 7 & Bali & 52 & Rp. 151 trilyun & Rp. 1,9 trilyun \\
\hline 8 & Kalimantan Barat & 69 & Rp. 183 trilyun & Rp. 8,9 trilyun \\
\hline 9 & Kalimantan Timur & 67 & Rp. 830 trilyun & Rp. 7,5 trilyun \\
\hline 10 & Sulawesi Selatan & 169 & Rp. 883 trilyun & Rp. 1,8 trilyun \\
\hline
\end{tabular}

Sumber: Indonesia Corruption Watch, 2017

Dari data ini menunjukkan bahwa korupsi yang dilakukan oleh anggota legislatif sendiri sudah menjadi suatu yang jamak bagi kalangan legislatif tersebut, hal ini dikarenakan ada beberapa hal yang merupakan akar permasalah korupsi di kalangan legislatif itu sendiri, antara lain biaya politik yang tinggi yang harus dikeluarkan oleh para anggota DPR untuk maju dan memenangkan pemilihan umum. Di sisi yang lain, mereka juga harus merawat para konstituen mereka, dan hal tersebut membutuhkan biaya yang tinggi. Di sisi lainnya, setiap anggota partai politik yang menjadi anggota, mereka membebani kader mereka dengan pendanaan keuangan bagi partainya, atau mesin uang partainya, berlaku kondisi simbiosis mutualisme yang berusaha saling memberi keuntungan antara partai politik dan kadernya. Kemudian, keempat adalah tingginya konflik kepentingan yang terjadi di DPR, sementara regulasi yang mengatur mengenai hal tersebut masih sangat minim.

Pada sisi yang lain, para anggota legislatif ini juga ada yang berasal dari mantan napi yang sebelumnya tersangkut dengan kasus korupsi antara lain: 
Tabel 2. Calon Legislatif dari Berbagai Provinsi

\begin{tabular}{|c|c|c|}
\hline No & Nama Calon & Provinsi \\
\hline \multicolumn{3}{|c|}{ Partai Golkar } \\
\hline 1 & H. Achmad Junaidi Sunardi, SH & DPRD Provinsi Lampung \\
\hline 2 & Hamid Usman, SE & DPRD Provinsi Maluku Utara \\
\hline 3 & Desi Yusandi, SE & DPRD Provinsi Banten \\
\hline 4 & Petrus Nauw, SH & DPRD Provinsi Banten \\
\hline 5 & Heri Basianu, KA & DPRD Provinsi Pandeglang \\
\hline 6 & Dede Widarso & DPRD Provinsi Pendeglang \\
\hline 7 & Saiful T Lami, Msi & DPRD Provinsi Tojo Una-una \\
\hline 8 & Edy Mukhlison, S.Sos & DPRD Provinsi Blitar \\
\hline 9 & Christofel Wonatonel & DPRD Provinsi Waropen \\
\hline \multicolumn{3}{|c|}{ Gerindra } \\
\hline 1 & Mohammad Taufik & DPRD Provinsi DKI Jakarta \\
\hline 2 & Herry jones Johny Kereh & DPRD Provinsi Sulawesi Utara \\
\hline 3 & dr. Husen Kausaha, M.Kes & DPRD Provinsi maluku Utara \\
\hline 4 & Farizal SJP & DPRD Provinsi Belitung Timur \\
\hline 5 & Mirhammuddin & DPRD Provinsi Belitung Timur \\
\hline 6 & Hj. Al Hajjar Syahyan, SH, MH & DPRD Provinsi Tanggamus \\
\hline \multicolumn{3}{|c|}{ Partai Berkarya } \\
\hline 1 & H. Mukhlis, SE & DPRD Provinsi Sulawesi Selatan \\
\hline 2 & Meike L Nangka, SH & DPRD Provinsi Sulawesi Utara \\
\hline 3 & Drs. Hi Arief Armain, M.Si & DPRD Provinsi Maluku Utara \\
\hline 4 & Yohannes Marinus Kota, SE & DPRD Provinsi Ende \\
\hline 5 & Drs. Andi Muttamar Mottoropeng & DPRD Provinsi Bulukumba \\
\hline 6 & Drs. Zambri, MM & DPRD Provinsi Pasaman Barat \\
\hline 7 & Djokemon Amisi, SH & DPRD Provinsi Kepulauan Talaud \\
\hline \multicolumn{3}{|c|}{ Hanura } \\
\hline 1 & Muhammad Asril Ahmad & DPRD Provinsi Maluku Utara \\
\hline 2 & Wilhemus Tahelele, SE & DPRD Provinsi Maluku Utara \\
\hline 3 & H. Mudasir, SH, MH & DPRD Provinsi Jawa Tengah \\
\hline 4 & Akhmad Ibrahim, ST & DPRD Provinsi Maluku Utara \\
\hline 5 & HM. Warsit, Sp.Pd, SH, MM & DPRD Provinsi Blora \\
\hline
\end{tabular}




\begin{tabular}{|c|c|c|}
\hline No & Nama Calon & Provinsi \\
\hline 6 & Mohammad Nur Hassan, SH, MH & DPRD Provinsi Rembang \\
\hline 7 & Rachmad Santoso & DPRD Provinsi Kutai Kertanegara \\
\hline 8 & Drs. H. Darjis, AL. MM & DPRD Provinsi Ogan Ilir \\
\hline 9 & Ir. Andi Wahyu Etong, M.Si & DPRD Provinsi Pinrang \\
\hline 10 & H. Hassanuddin, SE & DPRD Provinsi Banjarnegara \\
\hline 11 & Bonar Zetsel Ambarita, SE, M. Si & DPRD Provinsi Simalungun \\
\hline \multicolumn{3}{|c|}{ Partai Demokrat } \\
\hline 1 & Ir. H Firdaus Djailani & DPRD Provinsi Bengkulu \\
\hline 2 & Jones Khan, S.Sos & DPRD Provinsi Pagar Alam \\
\hline 3 & Jhonny Husban, ST, MM & DPRD Provinsi Kota Cilegon \\
\hline 4 & Syamsuddin & DPRD Provinsi Lombok Tengah \\
\hline 5 & Darmawati Dareho, SH & DPRD Provinsi Kota Manado \\
\hline 6 & Drs. Farid Wijaya & DPRD Provinsi Pesisir Barat \\
\hline 7 & Imam Subandi & DPRD Provinsi Ogan Komering Ilir \\
\hline 8 & Syamsuddin Olil & DPRD Provinsi Bolaang Mangandow \\
\hline 9 & Rahmanuddin, Dh, S.Sos & DPRD Provinsi Luwu Utara \\
\hline 10 & Polman, S.Pd & DPRD Provinsi Simalungun \\
\hline \multicolumn{3}{|c|}{ Perindo } \\
\hline 1 & Drs. Samuel Buntuang & DPRD Prov. Gorontalo \\
\hline 2 & Zulkifli, ST & DPRD Kota Pagar Alam \\
\hline 3 & Andu Gunawan & DPRD Kabupaten Lampung Timur \\
\hline 4 & Drs. H. Ramadhan Umarsangaji, MM & DPRD Kota Pare-pare \\
\hline \multicolumn{3}{|c|}{ PKP Indonesia } \\
\hline 1 & Joni Kornellius Tondok, ST, MM & DPRD Kab. Toraja Utara \\
\hline 2 & Drs. Mathius Tungka & DPRD Kab. Poso \\
\hline 3 & Raja Zulhindra, SE & DPRD Kab. Indragiri Hilir \\
\hline 4 & Yuridis, SP & DPRD Kab. Indragiri Hulu \\
\hline \multicolumn{3}{|c|}{ PAN (Partai Amanat Rakyat) } \\
\hline 1 & H. Abdullah Fattah, SH & DPRD Prov. Jambi \\
\hline 2 & Bonanza Kusuma, SH, MH & DPRD Prov. Lampung \\
\hline 3 & Masril & DPRD Kab. Belitung Timur \\
\hline 4 & Muhammad Afrizal & DPRD Kab. Lingga \\
\hline 5 & Drs. H. Bahri Syamsu Arief & DPRD Kota Cilegon \\
\hline 6 & Firdaus Obrini & DPRD Kota Pagar Alam \\
\hline
\end{tabular}




\begin{tabular}{|c|c|c|}
\hline No & Nama Calon & Provinsi \\
\hline \multicolumn{3}{|c|}{ PKS (Partai Keadilan Sejahtera) } \\
\hline 1 & Maksum DG Manassa & DPRD Kabupaten Mamuju \\
\hline 2 & Muhammad Zen & DPRD Kabupaten Oku Timur \\
\hline \multicolumn{3}{|c|}{ PKB (Partai Kebangkitan Bangsa) } \\
\hline 1 & Usman Effendi, SE, MM & DPRD Kabupaten Pesawaran \\
\hline 2 & EU. K Lenta & DPRD Kabupaten Morowali Utara \\
\hline \multicolumn{3}{|c|}{ PPP (Partai Persatuan Pembangunan) } \\
\hline 1 & Emil Sifan, SH & DPRD Kabupaten Musi Banyuasin \\
\hline 2 & Ujang Hasan, ST & DPRD Kabupaten Bengkulu Tengah \\
\hline 3 & Rommy Krisna, S. Sos & DPRD Kota Lubuklinggau \\
\hline \multicolumn{3}{|c|}{ PDI Perjuangan } \\
\hline 1 & Abner Reinal Jitmau, S. Sos, MM & DPRD Provinsi Papua Barat \\
\hline 2 & Mat Muhizer & DPRD Kab. Pesisir Barat \\
\hline \multicolumn{3}{|c|}{ Partai Garuda } \\
\hline 1 & Ariston Moho & DPRD Kabupaten Nias Selatan \\
\hline 2 & Yulius Dakhri & DPRD Kabupaten Nias Selatan \\
\hline \multicolumn{3}{|c|}{ DPD RI } \\
\hline 1 & Dr. Ir. H. Abdullah Puteh, Msi & DPD Provinsi Aceh \\
\hline 2 & Drs. H. Abdillah, Ak & DPD Provinsi Sumatera Utara \\
\hline 3 & Hamzah & DPD Provinsi Bangka Belitung \\
\hline 4 & Ir. Hj. Lucianty, SE & DPD Provinsi Sumatera Selatan \\
\hline 5 & Ririn Rosyana, SH & DPD Provinsi Kalimantan Tengah \\
\hline 6 & DR. La Ode Bariun SH, MH & DPD Provinsi Sulawesi Tenggara \\
\hline 7 & Drs. H. Mansyur Masie Abunawas, Msi & DPD Provinsi Sulawesi Tenggara \\
\hline 8 & Ir. A Yani Muluk, Msi & DPD Prov. Sulawesi Tenggara \\
\hline 9 & Syachrial Kui Damopli, S.Sos & DPD Provinsi Sulawesi Utara \\
\hline
\end{tabular}

\section{Pelaksanaan Kebijakan Mantan Narapidana Dalam Pencalonan Legislatif}

Pemilihan umum merupakan waktu yang tepat bagi parlemen dalam melakukan evaluasi kinerjanya. Di mana, hal tersebut bisa menjadi referensi untuk menggunakan hak pilih, yaitu bagi calon legislatif yang mempunyai rekam jejak yang buruk seharusnya dapat dicegah untuk terpilih kembali. Begitu sebaliknya, pemilihan umum juga bisa menjadi referensi untuk tidak memilih calon legislatif yang mempunyai rekam jejak yang buruk yaitu melakukan korupsi, kolusi, dan nepotisme. Data yang diperoleh dari ICW (Indonesia Corruption Watch) bahwa sepanjang tahun 2010 hingga tahun 2017 lalu, ada sedikitnya 215 kepala daerah yang ditetapkan sebagai tersangka kasus korupsi 
yang diketahui dan telah ditangani oleh pihak yang berwajib, di antaranya KPK, kepolisian dan kejaksaan. Angka yang memprihatinkan ini merupakan bentuk dari beragam kasus yang terjadi di antaranya berupa penyuapan, pengadaan barang dan jasa, penggelembungan dana dan lain lain.

Data ini menunjukkan bahwa korupsi yang dilakukan oleh anggota legislatif sudah menjadi suatu yang jamak bagi kalangan legislatf tersebut. Hal ini dikarenakan ada beberapa hal yang merupakan akar permasalahan korupsi di kalangan legislatif, antara lain, mereka juga harus merawat para konstituen mereka dan hal tersebut membutuhkan biaya yang tinggi. Di sisi lainnya, setiap anggota partai politik yang menjadi anggota, mereka membebani kader mereka dengan pendanaan keuangan bagi partainya, atau mesin uang partainya.

Grafik 1. Kepala Daerah Tersangka Korupsi 2010 - 2017

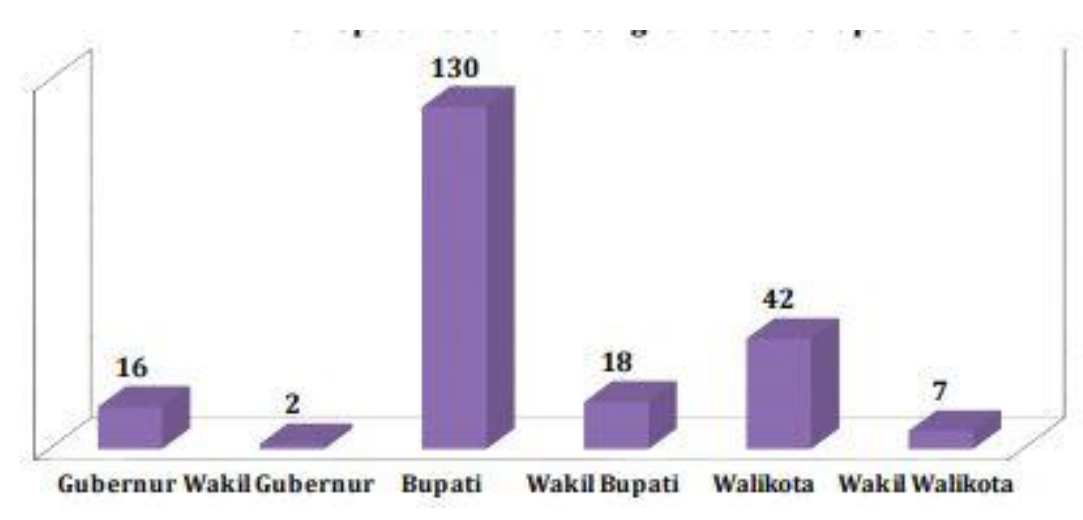

Sumber: Indonesia Corruption Watch, 2018

Tahun 2018, KPU menerbitkan PKPU Nomor 20 Tahun 2018 yang menyatakan bahwa mantan narapidana korupsi dilarang untuk mendaftarkan diri menjadi calon legislatif. Aturan itu tertera pada Pasal 7 ayat (1) huruf h, bahwa bakal calon anggota DPR, DPRD Provinsi, dan DPRD Kabupaten/Kota adalah Warga Negara Indonesia dan harus memenuhi persyaratan: "Bukan mantan terpidana bandar narkoba, kejahatan seksual terhadap anak, atau korupsi”. KPU sebagai lembaga pelaksana Undang-Undang tidak diperbolehkan untuk membuat suatu peraturan yang bertentangan dengan Perundang-undangan yang berada di atas hierarkinya. KPU dianggap melanggar UndangUndang Republik Indonesia Nomor 7 tahun 2017 tentang Pemilihan Umum. Dalam Undang-Undang tersebut, mantan narapidana yang sudah menjalani masa hukuman lima tahun atau lebih boleh mencalonkan diri sebagai anggota legislatif selama yang bersangkutan mengumumkan diri kepada publik mengenai kasus hukum yang pernah menjeratnya. Selain hal tersebut, pelarangan oleh KPU di atas dianggap bertentangan dengan Pasal 28 huruf D UUD RI Tahun 1945. Mantan narapidana kasus korupsi dianggap mempunyai hak politik yang sama dengan warga negara yang lain, yaitu suatu hak yang dijamin oleh konstitusi. Hal ini kemudian menimbulkan pro dan kontra yang berakibat pada 
permasalahan ini dibawa ke MK untuk dilakukan judicial review. Dalam putusannya, Mahkamah Konstitusi memperbolehkan mantan narapidana korupsi mendaftarkan diri menjadi anggota legislatif.

Pihak lainnya yang menyatakan keberatan yaitu melalui wawancara peneliti secara langsung dengan beberapa orang kader dan caleg dari beberapa partai yang memiliki pendapat pro dan kontra terhadap kondisi ini. Pendapat pertama dari Siti Noeryani, seorang anggota Partai Gerindra dan Sekretaris dari FKPPI Surabaya, yang menyatakan bahwa seharusnya aturan PKPU tetap diperbolehkan, karena untuk menjadi seorang legislatif atau wakil rakyat, tidak boleh mencederai rakyat karena tindakan korupsi berasal dari harta-harta rakyat yang digunakan untuk kepentingan pribadi. Adanya pertentangan ini hanyalah semacam arogansi partai yang mengizinkan. Pendapat dari pihak yang pro terhadap PKPU selanjutnya berasal dari Shobikin, Ketua DPW Partai Solidaritas Indonesia Surabaya, yang menyatakan bahwa PSI setuju terhadap PKPU dan menolak adanya mantan narapidana korupsi yang mencalonkan diri sebagai anggota legislatif. Sebagaimana DNA PSI yaitu anti korupsi dan anti diskriminasi. Sehingga PSI akan sangat tidak menoleransi kepada koruptor yang akan mendaftarkan diri sebagai caleg. Pendapat tersebut menunjukkan bahwa seorang mantan napi korupsi adalah seseorang yang sudah cacat secara kredibilitas, sementara sebagai calon legislatif haruslah seseorang yang memiliki track record atau moralitas yang bersih.

Berbeda halnya dengan pendapat yang disampaikan oleh Ernando Rahagi, anggota partai Golkar. Ia tidak setuju dengan adanya PKPU. Menurutnya, mantan narapidana korupsi seharusnya tetap diperbolehkan mendaftarkan diri sebagai calon legislatif. Karena hal tersebut bertentangan dengan Undang-Undang, serta dirinya berpendapat bahwa seorang mantan napi korupsi juga memiliki hak yang sama dengan manusia lainnya yang dilindungi oleh Undang-Undang hak politiknya. Sehingga, seharusnya tetap diperbolehkan untuk melakukan kegiatan politik termasuk menjadi calon legislatif tanpa melihat bagaimana latar belakang mereka. Pendapat kontra terhadap PKPU selanjutnya langsung dari seorang mantan napi korupsi yang mendaftarkan diri sebagai caleg, Edy Muldison dari Fraksi Golkar. Ia menyatakan bahwa larangan yang tertuang dalam PKPU menjadi tidak relevan, karena di dalam Undang-Undang sendiri tidak melarang mantan napi korupsi untuk menjadi caleg, begitu pula dengan adanya putusan hakim yang tidak membatasi seseorang untuk berpolitik. Hal tersebut berkaitan dengan hak asasi manusia.

Berdasarkan hasil analisis, terdapat klasifikasi pada partai politik yang pro dan kontra terhadap larangan mantan narapidana diperbolehkan mencalonkan diri menjadi calon legislatif. Ada sejumlah partai yang sejak awal tidak mencalonkan caleg mantan napi korupsi, seperti Partai Kebangkitan Bangsa (PKB), Partai Persatuan Pembangunan (PPP), dan Partai Solidaritas Indonesia (PSI). Ada pula yang berniat untuk menarik calegnya yang berstatus eks koruptor dan mengganti dengan caleg yang bersih, seperti PDI Perjuangan dan Partai Perindo. Namun, ada juga partai yang bersikukuh usung caleg mantan napi koruptor, seperti Partai Demokrat, Partai Gerindra, hingga Partai Golkar.

Sehingga dengan adanya perdebatan pro dan kontra terhadap PKPU ini kemudian memunculkan tangan dari anggota KPU sendiri yaitu Bapak Wahyu Kuncoro. Menurutnya, dasar 
pertimbangan adanya pasal pelarangan mantan narapidana korupsi dalam mencalonkan menjadi anggota legislatif pada PKPU tersebut, yaitu Indonesia saat ini sedang mengarah pada suatu tatanan sosial politik yang sehat dan demokratis. Oleh karena itu, dalam menyelenggarakan dan mewujudkannya dibutuhkan adanya figur elite politik, pejabat publik, pejabat negara yang dapat memegang amanat masyarakat konstituen. KPU berkeinginan untuk mencari figur politik yang baik dan bersih. PKPU dianggap menjadi sebuah langkah preventif dan strategis dimana KPU berusaha sebaik mungkin menerapkan peraturan demi menjaga Indonesia dari kerugian - kerugian.

Namun, sesuai dengan Putusan Mahkamah Agung, bahwa mantan narapidana telah diperbolehkan mencalonkan diri menjadi calon legislatif, KPU tetap merespon putusan tersebut dengan positif dan menghormati apapun yang menjadi keputusan MA. Sebab KPU hanyalah sebagai lembaga penyelenggara Pemilu. Menurut Bapak Wahyu Kuncoro, tentu MA sudah memiliki pertimbangan yuridis dalam memutus sebuah perkara. Di satu sisi, PKPU memang tidak boleh berbenturan susunan perundang - undangan dengan yang lain. Tetapi, tetap ada tahapan atau mekanisme berupa transparansi profil dari para calon legislatif terkait, misalnya pernah melakukan tindak pidana korupsi. Dengan seperti itu, masyarakat menjadi tahu dan bisa menilai sendiri figur calon legislatif yang akan dipilih. Mengenai prosedur pencalonan legislatif, KPU mengaku tidak ada prosedur khusus yang harus dilakukan oleh mantan narapidana korupsi. KPU tetap melakukan profile tracking kepada semua calon legislatif, baik mantan narapidana atau bukan.

\section{SIMPULAN}

Pada pelaksanaan kebijakan mantan narapidana korupsi pada tingkat putusan MA ternyata tetap memperbolehkan bagi calon napi untuk mencalonkan diri sebagai calon legislatif. Hal ini didasarkan pada beberapa pertimbangan, yaitu pertimbangan terkait Hak Asasi Manusia dan bertentangan dengan peraturan perundang - undangan yang lebih tinggi. Permasalahan ini menimbulkan berbagai pro dan kontra. Kubu yang menyetujui bahwa seorang napi koruptor tidak diperbolehkan menjadi calon legislative, menyatakan bahwa penilaian lebih banyak didasarkan pada aspek moral dan kredibilitas seseorang dimana menurutnya korupsi adalah suatu tindakan yang mencederai rakyat, karena mereka mengambil uang rakyat untuk kepentingan pribadi. Dengan mengembalikan mereka sebagai wakil rakyat adalah sesuatu yang tidak pantas, dan sebagai calon legislatif haruslah seseorang yang memiliki track record atau moralitas yang bersih. Sedangkan pada kubu yang tidak setuju bahwa seorang napi koruptor tidak diperbolehkan menjadi calon legislatif menyatakan bahwa kebijakan peraturan PKPU tersebut dinilai melanggar hak asasi manusia, dimana seorang mantan napi koruptor telah menjalani hukumannya, seharusnya dinilai sebagai manusia dengan hak-hak yang sama di mata hukum. Calon legistatif mantan napi itu dilindungi hak asasinya oleh perundang-undangan, sehingga bagaimanapun ia tidak boleh dibatasi hak politiknya. Selanjutnya, dalam aspek pelaksanaan, para caleg yang kontra dengan putusan MA tersebut berharap adanya mekanisme lebih lanjut terkait dengan bagi para caleg mantan koruptor yang ingin kembali mendaftar Pemilu, yakni dengan cara bersikap jujur dan terbuka 
pada publik mengenai cacat kredibilitas tersebut, agar kemudian publik bisa menilai sendiri secara langsung, bagaimana kondisi, keadaan dan latar belakang mereka sebelum mereka memutuskan untuk memilih.

Kemudian pada aspek peranan KPU menanggapi putusan MA mengenai narapidana dalam pencalonan legislatif, KPU merespon secara positif dan menghormati apapun yang menjadi keputusan MA. Sebab posisi KPU hanyalah sebagai lembaga penyelenggara Pemilu, sehingga harus tunduk pada aturan yang lebih tinggi. Namun, pada proses pendaftaran calon legislative, KPU tetap memberlakukan tracking pada profil caleg, jika ada catatan pidana akan diumumkan secara terbuka sehingga masyarakat akan bisa menilai sendiri secara lebih dewasa mengenai kondisi calon-calon legislatifnya. Karena tujuan awal dari PKPU tersebut, yaitu sebagai sebuah langkah preventif dan strategis dimana KPU berusaha sebaik mungkin menerapkan peraturan-peraturan demi menjaga Indonesia dari kerugian-kerugian.

\section{DAFTAR PUSTAKA}

Budiarjo M \& Ibrahim A (1993) Fungsi legislatif dalam Sistem Politik Indonesia. Jakarta: Raja Grafindo Persada.

Gentzkow M, Glaeser E, Goldin C (2006) The rise of the fourth estate: How newspapers became informative and why it mattered. National Bureau of Economic Research.

Hapsari H (2018) Dilema pelarangan mantan narapidana korupsi mendaftarkan diri sebagai calon legislatif. Seminar Nasional Hukum Universitas Semarang, 6(2).

Huda K \& Zulfa AF (2018) Pemilu presiden 2019: Antara kontestasi politik dan persaingan pemicu perpecahan bangsa. Seminar Nasional Hukum Universitas Negeri Semarang, 4(3).

Nye JS (2009) Corruption and Political Development: A Case-Benefit Analysis. In Heidenheimer AJ and Johnston M. (Eds.) Political Corruption, Concepts and Contexts. Third Ed. New Jersey: Transaction Publishers.

Pipit (2014) Demokrasi Elektoral (Bagian I): Perbandingan Sistem dan Metode dalam Kepartaian dan Pemilu. Surabaya: Sindikasi Indonesia.

Wiener A (2004) A Theory of Contestation. Germany: Springer. 